\title{
Etiology and Clinical Characteristics of Pediatric Dizziness
}

\author{
Hyung Min Lee ${ }^{1}$, Jihun Park ${ }^{1}$, Bumsang Lee ${ }^{1}$, Kon Hee Lee ${ }^{2}$, Su-Kyoung Park ${ }^{1}$, and Jiwon Chang ${ }^{1}$ \\ ${ }^{I}$ Departments of Otorhinolaryngology-Head and Neck Surgery, ${ }^{2}$ Pediatrics, Kangnam Sacred Heart Hospital, \\ Hallym University College of Medicine, Seoul, Korea
}

\section{소아 어지럼의 원인과 임상 양상}

이형민 ${ }^{1} \cdot$ 박지훈 $^{1} \cdot$ 이범상 ${ }^{1} \cdot$ 이건희 $^{2} \cdot$ 박수경 $^{1} \cdot$ 장지원 $^{1}$

한림대학교 의과대학 강남성심병원 이비인후과학교실, ${ }^{1}$ 소아과학교실 ${ }^{2}$

\author{
Received July 26, 2017 \\ Revised October 25, 2017 \\ Accepted October 27, 2017 \\ Address for correspondence \\ Jiwon Chang, MD, PhD \\ Department of Otorhinolaryngology- \\ Head and Neck Surgery, \\ Kangnam Sacred Heart Hospital, \\ Hallym University \\ College of Medicine \\ 1 Singil-ro, Yeongdeungpo-gu, \\ Seoul 07441, Korea \\ Tel $+82-2-829-5217$ \\ Fax +82-2-842-5217 \\ E-mail brune77@naver.com \\ Address for correspondence \\ Su-Kyoung Park, MD, PhD \\ Department of Otorhinolaryngology- \\ Head and Neck Surgery, \\ Kangnam Sacred Heart Hospital, \\ Hallym University \\ College of Medicine, \\ 1 Singil-ro, Yeongdeungpo-gu, \\ Seoul 07441, Korea \\ Tel +82-2-829-5217 \\ Fax +82-2-842-5217 \\ E-mail ashock@daum.net
}

Background and Objectives Dizziness is not uncommon in children. The etiology of dizziness varies according to different studies due to different methods of examination or characteristics of the dizziness center. To assess meaningful causes of dizziness in children, a multidisciplinary approach would be needed. The purpose of this study was to analyze the main pathologies associated with vertigo and dizziness in children, paying particular attention to recent diagnostic advances with a multidisciplinary approach.

Subjects and Method A total of 73 children, aged between 4-18 years, who visited the Pediatric Dizziness Clinic of the University Hospital from January 2016 to June 2016 were included in this study. Medical records were reviewed retrospectively. All of the subjects were examined by history, questionnaires, physical examinations, electrocardiogram, hematologic tests, brain MRI scan, audiogram and vestibular function tests. Patients who had orthostatic symptoms additionally underwent a tilt table test, and in selective cases, a caloric and vestibular evoked myogenic potential tests as well.

Results Vestibular migraine (VM) and benign paroxysmal vertigo of childhood (BPVC) were found in $35.6 \%$ and $27.4 \%$ of the children with dizziness, respectively. The incidence of orthostatic hypotension and postural orthostatic tachycardia syndrome were $12.3 \%$ each, both of which are higher than other previous reports. Other causes were Meniere's disease, benign paroxysmal positional vertigo, vestibular neuritis and so on.

Conclusion VM and BPVC were the most common causes of pediatric dizziness. Also, the incidence of orthostatic dizziness was rather high in pediatric population. The evaluation of dizziness in children should include a thorough check of history (questionnaire), neurotological examination, vestibular function tests and a tilt table test.

Korean J Otorhinolaryngol-Head Neck Surg 2018;61(9):459-64

Key Words Dizziness $\cdot$ Migraine $\cdot$ Orthostatic $\cdot$ Pediatric $\cdot$ Vestibular function test.

\section{서 론 \\ 소아에서 어지럼은 성인보다는 낮은 빈도로 발생하지만 드 \\ This is an Open Access article distributed under the terms of the Creative Commons Attribution Non-Commercial License (https://creativecommons.org/licenses/by-nc/4.0) which permits unrestricted non-commercial use, distribution, and reproduction in any medium, provided the original work is properly cited.}

문 증상은 아니며, 전체 소아의 어지럼 유병률은 $0.7 \%$ 에서 $15 \%$ 로 알려져 있다. ${ }^{1-3)}$ 또한 소아에서 $60 \%$ 정도까지 어지럼 과 함께 동반하는 두통을 호소하였고, 환아의 약 절반이 어 지럼으로 인해 하던 활동을 멈추어야 한다고 하였으며, 약 $20 \%$ 에서 이명, $17 \%$ 에서 난청이 동반된다고 보고하였다.,5) 소아에서 어지럼 및 다양한 증상은 환아뿐 아니라 보호자에 
게도 불편감 및 공포감을 불러일으킬 수 있어서 정확한 진단 과 치료가 필요하다.

소아에서는 어지럼 진단 시 가장 중요한 병력 청취가 쉽지 않아 진단 역시 쉽지 않고, 또한 진료 시 많은 어려움이 발생 한다. 소아는 증상을 스스로 표현할 수 있는 능력이 부족한 경우가 많고, 보호자의 의견에 의존해야 하는 경우가 많은 데, 이로 인해 어린 소아일수록 증상 및 진단이 모호한 경우 가 종종 발생한다. 또한 진단을 위해서는 신경이학적검사 및 전정기능검사 등이 필요한데, 소아의 경우 검사의 협조가 어 렵고, 주의지속시간이 짧아서, 이를 극복하기 위해 환아에게 편안한 환경에서 검사를 시행하는 것이 필요하다.

소아에서의 어지럼증은 성인과 질환 분포가 다른 것으로 알려져 있으며, 소아 어지럼증의 가장 흔한 원인은 소아 양성 돌발현훈(benign paroxysmal vertigo of childhood)과 전정 편두통(vestibular migraine)으로 전체 어지럼의 약 $35 \%$ 정도 에서 진단되는 것으로 보고된다. ${ }^{6,7)}$ 하지만 환아의 연령에 따 라 유병률 및 질환 분포가 다르게 보고되고, 병원의 특성과 검사방법 및 접근방법에 따라 질환 분포가 다르게 나타날 수 있다. 그러므로 어지럼으로 내원한 환아를 다학제 간의 접근 을 통해 파악할 수 있다면, 전체 소아를 대표할 수 있는 유병 률 및 연령에 따른 질환 분포를 확인할 수 있을 것이다.

본 연구는 어지럼을 주소로 본원 소아어지럼클리닉에 내원 한 소아에서 어지럼의 원인을 알아보고, 연령에 따른 질환의 분포와 전정기능검사 결과에 대한 정보를 제공하기 위해 시 행되었다.

\section{대상 및 방법}

2016년 1월부터 6월까지 어지럼을 주소로 본 병원 소아어 지럼클리닉에 내원한 4 18세 사이의 소아 73명을 대상으로 후향적 의무기록 분석을 시행하였다. 모든 환자에게서 병력 청취 및 어지럼 설문지를 시행하였으며 신경이학적검사, 혈액 검사, 심전도검사, 청력검사, 전정기능검사 및 뇌 자기공명영 상을 시행하였다. 이 중 기립성어지럼이 있는 경우 기립경사 대검사(tilt table test)를 추가로 시행하였다.

청력검사는 순음청력검사 또는 이음향방사검사를 시행하 였고, 전정기능검사는 비디오안진검사(자발안진, 주시안진, 두 위안진, 두진후안진)와 신속안구운동(saccade), 추종안구운동 (pursuit), 비디오 두부충동검사(video head impulse test)를 기본적으로 시행하였으며 이명이나 이충만감 등의 증상이 있는 경우 전기와우도검사를 시행하였다. 비디오안진검사나 두부충동검사나 신속 및 추종안구운동에서 이상소견이 보 일 경우 필요에 따라 온도안진검사(caloric test)와 전정유발 근전위(vestibular evoked myogenic potential)를 시행하였다.

환자의 기왕력과 검사결과를 바탕으로 이비인후과 전문의 와 소아신경과 전문의가 상의하여 진단명을 결정하였는데, 이비인후과와 소아신경과에서 각각 환아에 대한 초기진단을 내리고, 진단명이 일치하는 경우는 진단명을 채택하였고, 진 단명이 일치하지 않는 경우는 상의하여 주진단명을 정하였 다. 주진단명 외에 부진단명이 있으면 추가하여 진료 시 참고 하였지만, 분석에는 주진단명만 적용하였다. 소아의 양성돌 발현훈과 전정편두통은 각각 2013년 Internal Headache Society, 2012년 Barany Society 진단기준(Table 1) ${ }^{8,9)}$ 을 참고 하였고, 기립성저혈압은 기립경사대검사에서 기립 3 분 이내에 수축기 혈압이 $20 \mathrm{~mm} \mathrm{Hg}$ 이하 또는 이완기 혈압이 $10 \mathrm{~mm} \mathrm{Hg}$ 이하로 감소하는 소견을 보일 때 진단하였다. 체위성기립빈맥 증후군(postural orthostatic tachycardia syndrome, POTS) 은 기립경사대검사 시 심박 수를 측정하여 진단하였는데, 12 세 이하의 소아에서 심박 수가 40회 이상 증가하거나 13세 이 상의 소아에서 심박 수가 30회 이상 증가하였을 때 이를 체위 성기립빈맥증후군으로 진단하였다. ${ }^{10)}$ 메니에르병은 1995 년 미국이비인후과학회에서 제정한 진단기준을 참고하여 진단 하였다.

순음청력검사상 청력역치(500, 1000, 2000, $3000 \mathrm{~Hz})$ 가

Table 1. Diagnostic criteria for BPVC and $\mathrm{VM}^{8,9)}$

양성돌발현훈(BPVC)

A. 진단기준 $B$ 와 $C$ 를 충족하며 최소한 5 번 발생하는 발작

B. 경고 증상 없이 갑자기 나타나며, 발생 당시 가장 심하고, 의식 소실 없이 수 분에서 수 시간 후 저절로 사라지는 현훈

C. 다음 관련 증상 및 징후 중 적어도 하나 이상 동반: 안진, 실조, 구토, 창백, 두려움

D. 발작과 발작 사이에는 신경학적 검사와 청각 및 전정기능 정상

E. 다른 질환으로 더 잘 설명되지 않음

전정편두통( $\mathrm{VM}$, definite)

A. 5 분 72 시간 유지되는 중등도 이상의 전정발작이 5 회 이상

$\mathrm{B}$. 국제두통분류 $(\mathrm{ICHD})$ 에 따른 현재 혹은 과거의 편두통(전조가 있는 혹은 없는)

C. 전정 증상 $50 \%$ 이상에서 아래의 편두통 양상이 동반

- 다음 중 두 가지 이상의 특징을 가진 두통

: 편측성, 박동성, 중등도 이상의 통증 강도, 일상생활에 의해 악화

- 광과민성 또는 소리 과민성

- 시각 전조

D. 다른 전정질환으로 더 잘 설명이 되지 않음 전정편두통(VM, probable)

A. 5 분 72시간 유지되는 중등도 이상의 전정발작이 5 회 이상

B. 앞의 B, C의 기준 중 한 가지만 충족(편두통의 병력 또는 편두통의 특성)

C. 다른 전정질환으로 더 잘 설명이 되지 않음

BPVC: benign paroxysmal vertigo of childhood, VM: vestibular migraine, ICHD: The International Classification of Headache Disorders 
$25 \mathrm{~dB}$ 이상인 경우를 이상소견으로 하였으며, 비디오 두부충 동검사에서는 이득(gain)이 0.7 이하 혹은 1.25 이상이거나 현 성신속안구운동(overt saccade)이 관찰되는 경우 이상소견 으로 판독 내렸고, 전기와우도검사는 summating potential/ action potential(SP/AP) ratio 0.35 이상을 이상소견으로 정의 하였다. 온도안진검사에서는 반고리관마비(canal paresis)가 $25 \%$ 이상인 경우에 이상소견으로 하였고, 전정유발근전위 는 누운 자세로 측정한 양측의 p13-n23 amplitude에 25\% 이상의 비대칭이 있을 경우 이상소견으로 보았다. ${ }^{11}$

통계학적 분석은 SPSS(version 24.0; IBM Corp., Armonk, $\mathrm{NY}, \mathrm{USA}$ )의 chi-square를 이용하였으며 통계학적 유의수준 은 $p<0.05$ 로 하였다. 이 연구는 본 병원의 연구심의 승인을 받아 진행하였다(IRB No. 2018-03-006).

\section{결 과}

총 73명의 환자 중 남아는 22명(30.1\%), 여아는 51명(69.9\%) 이었고, 소아의 평균연령은 $10.2 \pm 3$.세였다. 학령기에 따라 연 령군을 나누었으며, 학령전기인 6세 이하는 15 명(20.5\%), 초 등학교 저학년인 7 9세는 19명(26.0\%), 초등학교 고학년인 10 12세는 19명(26.0\%), 중학생인 13 15세는 15명(20.5\%), 고등학생인 16 18세는 5명(6.8\%)으로 골고루 분포하고 있었 다(Fig. 1).

어지럼의 원인을 질환별로 분류해 본 결과 전정편두통과 양성돌발현훈이 각각 $35.6 \%, 27.4 \%$ 로 가장 높은 비중을 차 지하였다. 그리고 뒤를 이어 기립성저혈압이 $12.3 \%$, 체위성기 립빈맥증후군(POTS)이 $12.3 \%$ 로 이전의 문헌들보다 높은 비 중을 보였다. 이 외에 메니에르병, 전정신경염, 양성돌발두위 현훈(benign paroxysmal positional vertigo)이 각각 $2.7 \%$, $1.4 \%, 1.4 \%$ 의 비중을 차지했다(Table 2). 기타로 분류된 환자 는 총 5 명으로 전정편두통이나 기립성어지럼의 진단기준에 포 함되지 않는 두통 관련 어지럼 2명, 자율신경계 관련 어지럼 3명이었다.

연령별로 어지럼 질환의 차이가 있었는데( $p=0.00)$ (Fig. 2), 6 세 이하에서는 양성돌발현훈이 9예, 전정편두통이 1예, 기립 성저혈압이 2예, 메니에르병이 2예였으며, 전정신경염이 1예 있 었다. 7 9세에서는 양성돌발현훈이 8예, 전정편두통이 6예, 기립성저혈압이 1예, 체위성기립빈맥증후군이 1예, 기타가 3 예였고, 10 12세에서는 양성돌발현훈이 2예, 전정편두통이 9예, 기립성저혈압이 4예, 체위성기립빈맥증후군이 3예, 기타 가 1예였다. 13 15세에서는 양성돌발현훈이 1예, 전정편두통 이 5예, 기립성저혈압이 2예, 체위성기립빈맥증후군이 4예, 양 성돌발두위현훈이 1예, 기타가 1예였고, 16 18세에서는 전정

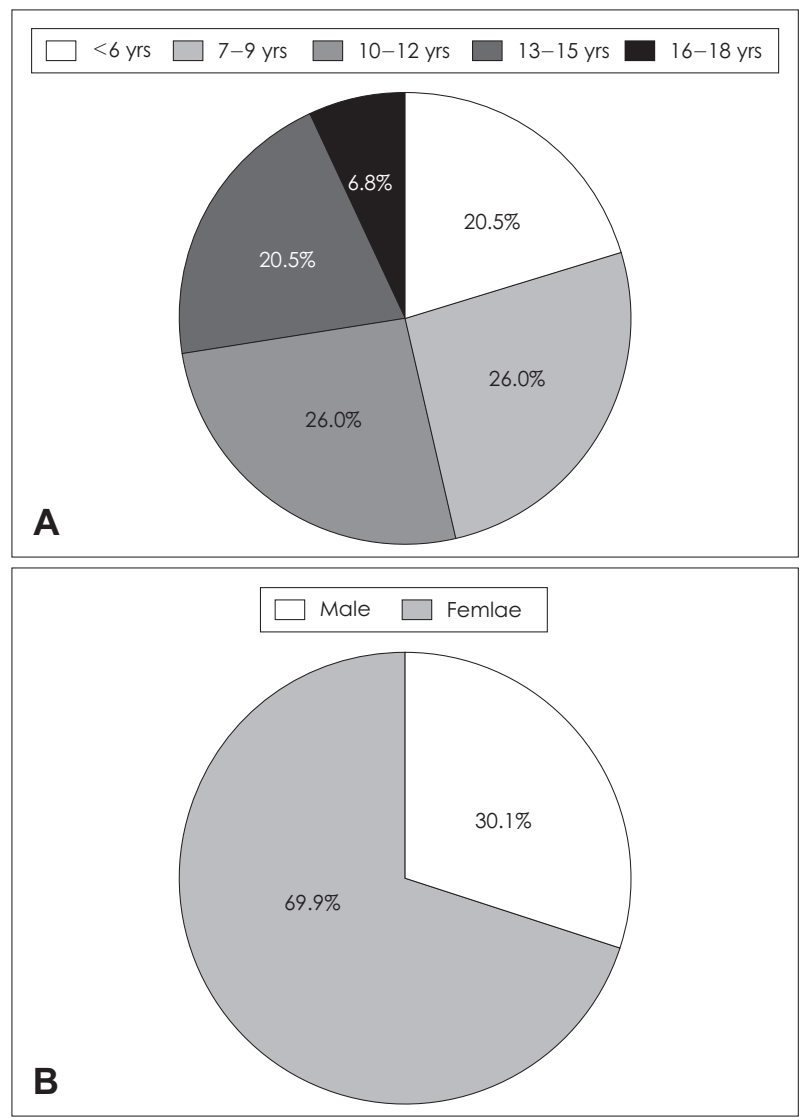

Fig. 1. Characteristics of patients. Seventy three patients aged 4-18 years were included in the study; 15 patients (20.5\%) were under 6 years old, 19 patients $(26.0 \%)$ were between $7-9$ years old, 19 patients $(26.0 \%)$ were between $10-12$ years old, 15 patients (20.5\%) were between $13-15$ years old, and 5 patients $(6.8 \%)$ were between $16-18$ years old. The median age was 10.2 years (A). Among the 73 patients, $22(30.1 \%)$ were male, and $51(69.9 \%)$ were female $(B)$.

편두통이 5예, 체위성기립빈맥증후군이 1예였다.

질환별로 살펴보면(Table 2) 양성돌발현훈은 평균연령은 7.3세, 남녀비 1:2.3으로 여아에서 더 흔한 양상을 보였다. 비 디오안진검사에서 이상을 보인 경우는 1 명 있었고, 신속안구 운동 및 추종안구운동에서 이상을 보인 경우는 4명이었다. 전기와우도검사에서 $\mathrm{SP} / \mathrm{AP}$ 비율이 증가한 경우는 3명이었고, video head impulse test(vHIT)에서 이상소견이 관찰되는 경 우는 7명 있었다. 전정편두통은 평균연령은 12.1 세로 소아 양 성돌발현훈보다 조금 높은 연령에서 발생하였고, 남녀 비는 1:1.5로 역시 여아에서 더 흔했다. 비디오안진검사에서 이상을 보인 경우는 4명이고, 신속안구운동 및 추종안구운동에서 이 상을 보인 경우는 4명이었으며, 전기와우도검사에서 SP/AP 비율이 증가한 경우는 5 명이었다. vHIT에서 이상소견이 관찰 되는 경우는 9명이었다. 이 군에서 온도안진검사를 시행한 6 명 가운데 $25 \%$ 이상의 반고리관 마비가 있는 경우는 3 명 있었고, 전정유발근전위검사를 시행한 4 명 중에 1 명이 비대칭이 관찰 
Table 2. Abnormal results on VNG and vestibular function tests according to the causes of dizziness

\begin{tabular}{lccccccccc}
\hline $\begin{array}{c}\text { Causes } \\
\text { of dizziness }\end{array}$ & $\mathrm{N}(\%)$ & $\begin{array}{c}\text { Sex } \\
(\mathrm{m}: \mathrm{f})\end{array}$ & $\begin{array}{c}\text { Age } \\
(\text { mean } \pm \text { SD) }\end{array}$ & $\begin{array}{c}\text { Abnormal } \\
\text { VNG }\end{array}$ & $\begin{array}{c}\text { Saccade } \\
\text { pursuit }\end{array}$ & $\begin{array}{c}\text { Elevated } \\
\text { SP/AP }\end{array}$ & $\begin{array}{c}\text { Abnormal } \\
\text { vHIT }\end{array}$ & $\begin{array}{c}\text { Canal } \\
\text { paresis }\end{array}$ & $\begin{array}{c}\text { VEMP } \\
\text { asymmetry }\end{array}$ \\
\hline BPVC & $20(35.6)$ & $6: 14$ & $7.3 \pm 2.3^{\dagger}$ & $1 / 20^{*}$ & $4 / 20$ & $3 / 20$ & $7 / 19$ & $0 / 2$ & $0 / 0$ \\
VM & $26(27.4)$ & $6: 20$ & $12.1 \pm 3.5^{\dagger}$ & $4 / 26$ & $4 / 26$ & $5 / 25$ & $9 / 25$ & $3 / 6$ & $1 / 4$ \\
OH & $9(12.3)$ & $3: 6$ & $10.0 \pm 3.6$ & $0 / 9$ & $2 / 9$ & $2 / 7$ & $5 / 9$ & $0 / 2$ & $1 / 1$ \\
POTS & $9(12.3)$ & $1: 8$ & $12.9 \pm 2.7$ & $1 / 9$ & $1 / 9$ & $2 / 8$ & $3 / 9$ & $0 / 2$ & $1 / 2$ \\
Meniere & $2(2.7)$ & $1: 1$ & $5.0 \pm 1.4$ & $0 / 2$ & $0 / 2$ & $2 / 2$ & $0 / 2$ & 0 & 0 \\
Vestibular neuritis & $1(1.4)$ & $0: 1$ & 6.0 & $1 / 1$ & $1 / 1$ & $0 / 1$ & $1 / 1$ & $1 / 1$ & $1 / 1$ \\
BPPV & $1(1.4)$ & $0: 1$ & 13.0 & $1 / 1$ & $0 / 1$ & $0 / 1$ & $1 / 1$ & $0 / 1$ & $0 / 1$ \\
Etc & $5(6.8)$ & $5: 0$ & $9.8 \pm 1.9$ & $0 / 5$ & $1 / 5$ & $0 / 5$ & $0 / 5$ & $0 / 0$ & $0 / 1$ \\
\hline Total & 73 & $22: 51$ & $10.2 \pm 3.7$ & $8 / 73$ & $13 / 73$ & $14 / 69$ & $26 / 71$ & $4 / 14$ & $4 / 10$ \\
\hline
\end{tabular}

*all the data are presented with 'number of patients with abnormal finding/number of patients who conducted the test', tage difference between two groups were statistically significant $(p<0.05)$. VNG: videonystagmography, SP/AP: summating potential/ action potential, vHIT: video head impulse test, VEMP: vestibular evoked myogenic potential, BPVC: benign paroxysmal vertigo of childhood, VM: vestibular migraine, OH: orthostatic hypotension, POTS: postural orthostatic tachycardia syndrome, BPPV: benign paroxysmal positional vertigo, Etc: headache-related dizziness 2; dizziness related to autonomic dysfunction 3

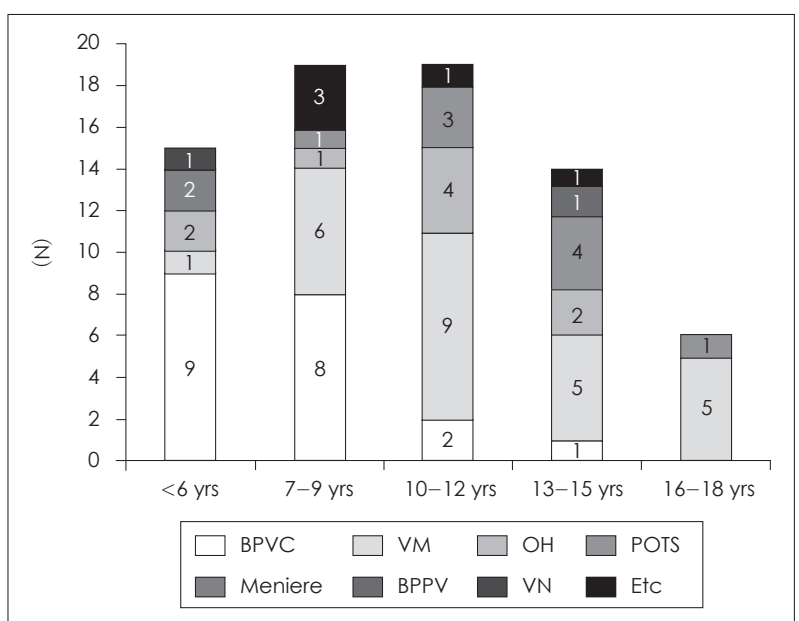

Fig. 2. Causes of dizziness according to age distribution. The etiology of dizziness in different age groups was inconsistent $(p=$ 0.000). BPVC: benign paroxysmal vertigo of childhood, VM: vestibular migraine, $\mathrm{OH}$ : orthostatic hypotension, POTS: postural orthostatic tachycardia syndrome, BPPV: benign paroxysmal positional vertigo, VN: vestibular neuritis, Etc: headache-related dizziness 2; dizziness related to autonomic dysfunction 3 .

되었다. 기립성저혈압은 평균연령은 10세, 남녀 비 1:2로 여 아에서 더 흔한 양상을 보였다. 비디오안진검사는 정상으로 나타났지만, 신속안구운동 및 추종안구운동에서 이상을 보 인 경우는 2 명이었다. 전기와우도검사에서 $\mathrm{SP} / \mathrm{AP}$ 비율이 증 가한 경우는 2 명이었고, $\mathrm{vHIT}$ 에서 이상소견이 관찰되는 경 우는 5명 있었다. 1명에서 전정유발근전위에서 양측 간 비대 칭이 관찰되었다. 체위성기립빈맥증후군은 평균연령은 12.9 세에서 발생하였고, 남녀 비 1:8로 여아에서 더 흔한 양상을 보였다. 비디오안진검사상 1 명에서 이상소견이 나타났으며, 신 속안구운동 및 추종안구운동에서 이상을 보인 경우는 1명이 었다. 전기와우도검사에서 SP/AP 비율이 증가한 경우는 2명 이었고, vHIT에서 이상소견이 관찰되는 경우는 3 명 있었다.
1 명에서 전정유발근전위에서 양측 간 비대칭이 관찰되었다. 전형적인 definite나 probable 메니에르병이 나타나는 소아 는 없었으며, 이명 및 이충만감을 동반하는 회전성어지럼을 호소하는 환아를 메니에르병(possible)으로 진단할 수 있었 다. 시행한 순음청력검사는 정상이었고, 1 명에서 비디오안진 검사상 이상소견이 나타났으며, 2 명 모두 전기와우도검사에 서 $0.38,0.39$ 등으로 SP/AP 비율이 증가되어 있었다. 그 외에 전정신경염이 있는 경우는 1 예, 양성돌발두위현훈이 있는 경 우는 1예, 편두통 연관 어지럼 2예, 자율신경계 이상에 의한 어지럼 3예가 있었다.

혈액검사 및 심전도검사에서 이상이 있는 경우는 전체 73명 중 2 명으로 혈액검사에서 당뇨로 진단된 환아가 1 예, hemoglobin 5.0의 심한 빈혈이 있는 환아가 1 예 있었다. 당뇨로 진 단된 환아는 양성돌발현훈으로 진단되었고, 당뇨는 우연히 발견된 것으로 어지럼과 큰 연관은 없을 것으로 판단되었으 며, 빈혈이 관찰된 환아는 기립성저혈압으로 진단되었으며 이는 빈혈과 연관되어 있는 것으로 판단하였다. 심전도검사 결과에서는 주요한 이상소견이 발견된 환아는 없었다.

\section{고 찰}

어지럼의 원인을 알아내기 위해서는 철저한 병력 청취와 신 체검진이 우선이 된다. 어지럼 문진 시에는 어지럼의 양상이 회전성의 현훈인지, 비회전성의 아찔함인지, 언제 시작되었 고, 얼마나 오래 지속되는지, 무엇을 할 때 심해지거나 완화 되는지, 두통이나 청각 증상을 동반하는지 등 환자 본인의 기억과 표현에 의존해야 하는 경우가 많다. 하지만 소아의 경 우에는 인지기능이 완전히 발달하지 않고 표현의 미숙함으 로 병력 청취가 정확히 되지 않는 경우가 종종 있게 된다. 그 
래서 소아의 어지럼은 성인에서보다 더 진단이 어렵고 지금까 지 발생 빈도도 저평가되어 왔다. 또한 문헌에 따라서 소아 어지럼의 원인에 대한 차이가 있는데, ${ }^{710,12-15)}$ 이러한 차이는 아마도 대상 환자군의 차이에 의한 것으로 생각된다. 이비인 후과 환자 중심에 대한 조사를 하였거나, 소아과 또는 신경 과 환자 중심에 대한 조사를 하는 경우에 따라 다른 결과가 나올 수 있다. 본 연구는 어지럼 및 두통을 주소로 내원한 환 자를 이비인후과 및 소아신경과 전문의가 같이 진료를 하는 소아어지럼클리닉 외래에 내원한 환자를 중심으로 하였으며, 이로 인해 보다 보편적인 어지럼 원인을 연령별로 확인할 수 있을 것으로 판단된다. 한편 본 연구에서 소아 어지럼의 원인 질환이 한 개의 진단명으로 모아지는 경우보다, 한 개 이상의 부진단명이 나오는 경우가 종종 있었는데, 이런 경우 특히 소 아과와 이비인후과의 진단이 다른 경우에는 상호 간의 논의 를 거쳐 증상에 가장 큰 영향을 미친다고 생각되는 진단명 한 개를 대표 진단으로 결정하여 결과에 포함시켰다.

한편 어지럼 원인을 진단할 때, 이비인후과와 소아신경과 에서 초기 진단명이 일치한 경우는 46예(63\%)였으며, 일치하 지 않는 경우는 27예(37\%)였다. 일치하지 않는 가장 많은 경 우는 소아신경과에서는 두통 관련 어지럼으로 진단을 했으 나 이비인후과에서는 전정병증으로 진단을 한 경우로 7예가 있었으며, 최종적으로 상의하여 전정편두통 3예, 양성돌발현 훈 2예, 양성돌발두위현훈 1 예, 기립성저혈압 1 예로 최종진단 을 내렸다. 두 번째로 많이 일치하지 않은 경우는 소아신경과 에서는 기립성어지럼으로 진단을 했으나 이비인후과에서는 메니에르병으로 진단을 한 경우로 6건이 있었다. 이는 이비인 후과에서 환아가 회전성어지럼 및 이충만감을 동반하였고, 전기와우도검사상 SP/AP 비율이 증가되어 있어 메니에르병 (possible)으로 진단을 내렸던 경우로, 소아신경과와 상의하 여 초기진단 두 가지 모두 염두에 두고 치료를 시작하였고, 최종적으로 기립성저혈압 3예, 체위성기립빈맥증후군 2예, 메니에르병 1 예로 진단을 내렸다. 또한 소아신경과에서는 기 립성어지럼으로 진단을 했으나 이비인후과에서는 두통 관련 어지럼으로 진단을 한 경우로 5건이 있었으며, 최종적으로 체 위성기립빈맥증후군 2예, 기립성저혈압 1예, 양성돌발현훈 2 예로 진단하였다. 그 외에 소아신경과에서 기립성어지럼으로 진단을 했으나 이비인후과에서는 전정병증으로 진단을 한 경우로 3건이 있었으며, 체위성기립빈맥증후군 1예, 기립성저 혈압 1예, 급성전정신경염 1예로 최종진단하였다. 이와 같이 두 과의 진단이 다른 경우에는 상의하여 최종진단을 하였고, 최종진단명만을 분석결과에 포함시켰다.

본원에서 시행한 연구결과에서 전반적인 소아 어지럼의 원 인 질환은 소아 양성돌발현훈과 전정편두통이 가장 높은 빈
도를 차지함을 알 수 있었다. 이는 이전의 문헌들에서 보고 된 것과 비슷하거나 보다 높은 내용으로 소아 어지럼의 약 $60 \%$ 가까운 비중을 차지했다. 또한 보다 어린 연령에서는 양 성돌발현훈이, 보다 나이가 많은 연령에서는 전정편두통이 나타났다.

본 연구에서의 결과가 이전의 문헌에서와 크게 달랐던 부 분은 기립성저혈압과 체위성기립빈맥증후군의 빈도이다. 기 립성어지럼은 기립성저혈압, 혈관미주신경실신(vasovagal syncope), 체위성기립성빈맥증후군 및 기립못견딤증(orthostatic intolerance) 등을 모두 포함하는 개념이다. 두통 환자 의 경우 기립성어지럼의 비율이 증가한다고 알려져 있는데, 기 립성어지럼의 증상으로는 서 있는 자세에서 발생하는 두통 과 아찔함, 피로감, 복통, 그리고 실신 등이 있다. ${ }^{16)}$ 기립성저 혈압은 3 분간 서 있거나 기립경사대검사에서 60 도 이상의 경 사로 세웠을 때 수축기 혈압이 $20 \mathrm{~mm} \mathrm{Hg}$ 이상 떨어지거나 이완기 혈압이 $10 \mathrm{~mm} \mathrm{Hg}$ 이상 떨어질 때로 정의한다. 혈관미 주신경실신은 서 있거나 기립경사대를 60도 이상 세웠을 때 맥박 상승 없이 수축기 혈압이 $25 \mathrm{~mm} \mathrm{Hg}$ 이상 떨어질 때 진 단 내릴 수 있으며, 신경유발저혈압이라고도 한다. 체위성기립 성빈맥증후군은 10 분 이상 서 있거나 기립경사대를 세우는 경우에 혈압이 떨어지는 대신 맥박이 40회 이상 증가하거나 최소 120 회/분 이상의 맥박 수를 보이는 것으로 정의한다. ${ }^{1718)}$ 이전의 문헌들에서는 기립성저혈압에 의한 어지럼의 빈도를 약 0.9 1.3\% 정도로 보고하였으나 본 연구에서는 기립성저혈 압 및 체위성기립성빈맥증후군이 각각 $12.6 \%$ 로 높은 빈도를 보였다. 이는 기존의 이비인후과적인 접근으로 시행하던 전 정기능검사 외에 기립경사대검사 등의 검사를 기립성어지럼 을 호소하는 환아 전체에서 시행했기 때문에 진단률이 올라 간 것으로 생각된다. 그러므로 두통과 어지럼을 동반하여 내 원하는 경우, 기립성어지럼을 염두에 두고 진료를 하는 것이 필요할 것으로 생각된다. ${ }^{18)}$

메니에르병의 경우, 새로운 진단기준(definite, probable Meniere)이 2015년 바라니학회에 의해서 발표가 되었지만, ${ }^{19)}$ 본 연구에서는 연구 기간 동안 소아에서 전형적인 이명 또는 이 충만감, 청력저하, 및 회전성어지럼 등의 증상을 모두 보이는 소아가 없었으므로, 1995년 진단기준(definite, probable and possible Meniere)을 사용하였다. 또한 본 연구에 포함된 소 아의 경우, 이뇨제를 사용하였을 때 증상이 호전되는 것을 확인할 수 있었다. 소아에서 메니에르병은 매우 드문 질환으 로 여러 연구에 의하면 0 4\% 정도로 빈도가 보고되고 있는 데, 본 연구에서도 $2.7 \%$ 로 낮은 빈도를 보이고 있었다.220-22) 추후 소아를 지속적으로 경과관찰하면서 환자 수를 늘리면, definite 및 probable 메니에르병에 해당하는 환아의 관찰도 
가능할 것으로 생각된다.

본 연구에서 양성돌발현훈 또는 전정편두통으로 진단받은 소아의 전정기능검사 소견은, 성인에서와 마찬가지로 진단을 유추하거나 예후를 예측하는 데 도움이 되는 일관성이 있거 나 확정적인 소견은 없었다. 전정편두통과 전정기능에 대한 다양한 연구결과가 보고되는데, 한 연구에서는 전정편두통 의 $20 \%$ 에서 수평 전정안반사의 이상소견, $50 \%$ 에서 자세 불 안정을 보고하였고, ${ }^{23)}$ 또 다른 연구에서는 전정편두통 환자 의 전정기능 평가 시 $53 \%$ 에서 중추성 또는 말초성 전정기능 장애가 있다고 보고했다. ${ }^{11)}$ 하지만, 아직 전정편두통의 예후나 임상 양상을 예측할 수 있는 전정기능검사 결과는 보고되고 있지 않다. 전정편두통 이외의 여러 질환에서 전정기능검사 의 다양한 이상소견이 관찰되므로, 질환에 따른 전정기능검 사 결과에 대해 추후 분석이 필요할 것으로 생각된다.

또한 본 연구는 이비인후과와 소아신경과가 공동으로 진료 한 73명을 대상으로 분석을 하였기에, 추후에 더 많은 환아 가 포함이 된다면, 다른 문헌에서 보고하는 삼출성중이염, 두 부외상, 심인성어지럼 등의 다양한 원인 질환을 확인하고, 더 정확한 질환의 유병률을 파악할 수 있을 것으로 생각된다.

소아 어지럼은 드문 질환이 아니며, 전정편두통과 양성돌발 현훈이 가장 많은 부분을 차지했고, 두 질환은 연령에 따라 다른 분포를 보였다. 또한 기립성저혈압과 체위성기립성빈맥 증후군이 비교적 높은 빈도로 발생하였다. 소아 어지럼 환자 를 진료 시에는 철저한 병력 청취(설문지), 비디오안진검사를 포함한 신경이학적 검사, 전정기능검사 및 기립성어지럼 진단 을 위한 검사가 포함되어야 할 것으로 생각된다.

\section{REFERENCES}

1) Riina N, Ilmari P, Kentala E. Vertigo and imbalance in children: a retrospective study in a Helsinki University otorhinolaryngology clinic. Arch Otolaryngol Head Neck Surg 2005;131(11):996-1000.

2) Bower CM, Cotton RT. The spectrum of vertigo in children. Arch Otolaryngol Head Neck Surg 1995;121(8):911-5.

3) Eviatar L, Bergtraum M, Randel RM. Post-traumatic vertigo in children: a diagnostic approach. Pediatr Neurol 1986;2(2):61-6.

4) Humphriss RL, Hall AJ. Dizziness in 10 year old children: an epidemiological study. Int J Pediatr Otorhinolaryngol 2011;75(3): 395-400.

5) Niemensivu R, Pyykkö I, Wiener-Vacher SR, Kentala E. Vertigo and balance problems in children--an epidemiologic study in Finland. Int J Pediatr Otorhinolaryngol 2006;70(2):259-65.

6) Strupp M, Brandt T. Diagnosis and treatment of vertigo and dizziness. Dtsch Arztebl Int 2008;105(10):173-80.

7) Gioacchini FM, Alicandri-Ciufelli M, Kaleci S, Magliulo G, Re M. Prevalence and diagnosis of vestibular disorders in children: a review. Int J Pediatr Otorhinolaryngol 2014;78(5):718-24.

8) Headache Classification Committee of the International Headache Society (IHS). The International Classification of Headache Disorders, 3rd edition (beta version). Cephalalgia 2013;33(9):629-808.

9) Lempert T, Olesen J, Furman J, Waterston J, Seemungal B, Carey J, et al. Vestibular migraine: diagnostic criteria. J Vestib Res 2012;22(4): 167-72.

10) Singer W, Sletten DM, Opfer-Gehrking TL, Brands CK, Fischer PR, Low PA. Postural tachycardia in children and adolescents: what is abnormal? J Pediatr 2012;160(2):222-6.

11) Lee JW, Jung JY, Chung YS, Suh MW. Clinical manifestation and prognosis of vestibular migraine according to the vestibular function test results. Korean J Audiol 2013;17(1):18-22.

12) Choung YH, Park K, Moon SK, Ryu SJ. Clinical characteristics and diagnostic classification of vertigo in children. Korean J OtolaryngolHead Neck Surg 2003;46(2):105-9.

13) Kim JH, Bok KH, Chung WH. Clinical characteristics of dizziness in children. J Korean Bal Soc 2006;5(2):242-7.

14) Balatsouras DG, Kaberos A, Assimakopoulos D, Katotomichelakis M, Economou NC, Korres SG. Etiology of vertigo in children. Int J Pediatr Otorhinolaryngol 2007;71(3):487-94.

15) Sommerfleck PA, González Macchi ME, Weinschelbaum R, De Bagge MD, Bernáldez P, Carmona S. Balance disorders in childhood: main etiologies according to age. Usefulness of the video head impulse test. Int J Pediatr Otorhinolaryngol 2016;87:148-53.

16) Thijs RD, Kruit MC, van Buchem MA, Ferrari MD, Launer LJ, van Dijk JG. Syncope in migraine: the population-based CAMERA study. Neurology 2006;66(7):1034-7.

17) Bogle JM, Goodman BP, Barrs DM. Postural orthostatic tachycardia syndrome for the otolaryngologist. Laryngoscope 2017;127(5):1195-8.

18) Qubty W, Kedia S. Dizziness and orthostatic intolerance in pediatric headache patients. Semin Pediatr Neurol 2016;23(1):71-8.

19) Lopez-Escamez JA, Carey J, Chung WH, Goebel JA, Magnusson M, Mandalà $\mathrm{M}$, et al. Diagnostic criteria for Menière's disease. J Vestib Res 2015;25(1):1-7.

20) Hausler R, Toupet M, Guidetti G, Basseres F, Montandon P. Menière's disease in children. Am J Otolaryngol 1987;8(4):187-93.

21) Yanagida M. Veritigo and equilibrium disturbance in children. Equilibrium Res 1986;45(4):345-57.

22) Fujii K, Ito Y, Mizuta K, Shirato H, Sawai S, Sakuma S, et al. Vertigo and equilibrium disturbance in children; a clinical study. Equilibrium Res 1994;53(3):374-80.

23) Langhagen T, Lehrer N, Borggraefe I, Heinen F, Jahn K. Vestibular migraine in children and adolescents: clinical findings and laboratory tests. Front Neurol 2015;5:292. 